\title{
Association of polymorphism at Exon-1 of the alpha 1-antitrypsin gene with milk production traits in Sahiwal and Karan Fries Cattle
}

\author{
Alok Kumar Yadav and Anupama Mukherjee
}

Received: 23 January 2019 / Accepted: 31 January 2019 / Published online: 18 April 2019

(C) Indian Dairy Association (India) 2019

\begin{abstract}
PCR-RFLP analysis of PCR products was carried out using Sph I /Paelenzyme for 100 Sahiwal cattle and 115 Karan Fries cattle. In Sahiwal cattle, 448 bp exhibited three genotypes viz., $\mathrm{AA}(448), \mathrm{AB}(448+313+135 \mathrm{bp})$, $\mathrm{BB}(313+135 \mathrm{bp})$ with corresponding genotype frequencies of $0.20,0.45,0.35$ and gene frequencies 0.42 (A) and 0.58 (B). In Karan Fries cattle, genotype frequencies were $0.29,0.21,0.50$ respectively with corresponding gene frequencies 0.39 (A) and 0.61 (B). These genotypes of 448 bp are highly significant for FL305DMY, FLTMY, FL305DSNFY and non significant for FL305 DFY and FL305DPY in Sahiwal. In Karan Fries cattle these genotypes are highly significant for FL305DMY, FLTMY, FL305DSNFY and FL305DPY and non significant for FL305DFY. AB genotype was superior for FL305DMY, FLTMY, FL305DSNFY traits and AA genotype was superior for FL305DFY and BB genotype was superior for FL305DPY trait in Sahiwal cattle and In Karan Fries Cattle, AB genotype was superior for all traits.
\end{abstract}

Keywords: Sahiwal, Karan Fries, Cattle, Alpha 1-antitrypsin gene, Milk constituents traits

Alok Kumar Yadav $(\bowtie)$

Division of Animal Genetics and Breeding,

ICAR-National Dairy Research Institute, Karnal-132001, Haryana, India

E-mail: alokvet1000@gmail.com; Phone: +91-9473917493

Anupama Mukherjee

Division of Animal Genetics and Breeding,

ICAR-National Dairy Research Institute, Karnal-132 001, Haryana, India

\section{Introduction}

India is a rich reservoir of genetic diversity in cattle with 43 recognized cattle breeds. The total number of cattle population was 190.90 million (37.28\% of total livestock population) out of which indigenous cattle population comprised of 151.17 million (19 ${ }^{\text {th }}$ Livestock Census, 2012). Milk is an important source of essential nutrients for lactating calves and a key raw material for human food preparations (Reinhardt et al. 2012). The total milk production in India was 132.43 million tons (cattle contributes $43.11 \%$ with 59.92 million tons milk) in 2012-13 (BAHS, 2014) and in terms of milk production, India ranks first in the world. As far as milk production is concerned Sahiwal is the best dairy breed of the Indian subcontinent. Sahiwal breed had been termed due to its habitat in Montgomery district of Pakistan which is now named as Sahiwal and in India, number of herds of this breed is maintained. This is a comparatively heavy breed with a symmetrical body and loose skin. This breed is therefore, also known as Lola (loose skin), Lambi Bar, Montgomery, Multani, Teli (Nivsarkar et al. 2000). The Karan Fries breed has been evolved from crossbreeding between Tharparkar and Holstein Friesian at the ICAR-National Dairy Research Institute, Karnal, Haryana. The breed has $50 \%$ inheritance from Friesian. The breed carries black patches and sometime is completely dark with white patches on the forehead and the switch of the poll. The udder is also dark with white patches in teats. The animals are extremely docile and very good yielders.

Alpha 1-antitrypsin (AAT), a strong protease inhibitor, also known as $\alpha 1$-protease inhibitor ( $\alpha$ 1PI), belongs to the super family of serpins or serine proteinase inhibitors in addition to others $\mathrm{C} 1$ esterase, antithrombin and $\alpha 1$-antichymotrypsin. AAT is a glycoprotein which forms a sodium dodecyl sulfate (SDS) staple complex with elastase. The molecular mass of AAT is about $52 \mathrm{kDa}$, and carbohydrates account for $15 \%$ of its mass (Carrell et al. 1982). The bovine AAT gene consists of five exons, spanning about $9 \mathrm{~kb}$ of genomic DNA and encoding a 416-AA protein. Alpha 1-antitrypsin (AAT) can protect vulnerable elastic tissues from degradation by neutrophil elastase, this is an important issue as protein degradation in bovine milk affects the quality of dairy products. 


\section{Materials and methods}

\section{Experimental animals and genomic DNA isolation}

The data for present study pertained to various milk production and milk composition traits were collected from history sheets and milk composition constituents registers, data on milk production and milk constituent records of 100 Sahiwal and 115 Karan Fries cattle spread over a period of 13 years period 2004 to 2016 were collected from Animal Genetics and Breeding division of ICAR-National Dairy Research Institute, Karnal, Haryana. Blood samples were collected from the targeted population. About $10 \mathrm{ml}$ of venous blood was collected aseptically from the jugular vein of the animals in a $15 \mathrm{ml}$ polypropylene centrifuge tube under sterile condition using $0.5 \mathrm{ml}$ of EDTA as an anticoagulant. The tube was shaken gently to facilitate thorough mixing of blood with the anticoagulant. The tubes containing blood samples were transported to the laboratory as soon as possible in an icebox containing ice packs and were stored in the refrigerator at $-20^{\circ} \mathrm{C}$ temperature until the isolation of DNA was done. Phenol extraction method as described by Sambrook and Russell, (2001) was used for isolation of genomic DNA. Horizontal submarine agarose gel electrophoresis was used to check the quality of genomic DNA. The purity of genomic DNA was checked by spectrophotometer. The $6 \mu$ l of genomic DNA of each sample was dissolved in $294 \mu \mathrm{l}$ of triple distilled water and spectrophotometer readings at $\mathrm{OD}_{260}$ and $\mathrm{OD}_{280}$ was recorded against $300 \mu \mathrm{l}$ double distilled water as a blank. Genomic DNA samples showing the OD ratio in the range of 1.7 to 1.9 was used further in the study.

\section{Amplification of targeted region of AATgenes}

Only good quality genomic DNA was used for amplification of Exon 1 of 448 bp of AAT by polymerase chain reaction under optimized conditions.

\section{F: 5'-ATGGCACTCTCCATCACGCG-3' R: 5'-CCACTAGCTTTGCACTCTCAT-3'}

Forward and reverse primers were used to amplify targeted region of AAT gene, which was reported by Li et al. (2010) the best amplification of the desired fragment was taken for further analysis. The standard programme is given as under (Table 01):

\section{Polymerase chain reaction amplification of targeted region of AAT genes}

Various annealing temperatures were tried for PCR amplification of AAT genes. Total volume of $25 \mu \mathrm{l}$ for each sample was used to set up the PCR reactions. The set of primer was used to amplify target regions of AAT genes in Sahiwal and Karan Fries cattle. The best results were obtained when amplification was performed in PCR thermal cycler (Eppendorf Germany) programmed for 32 cycles with an initial denaturation at $94^{\circ} \mathrm{C}$ for 05 minutes, denaturation at $94^{\circ} \mathrm{C}$ for 30 second, annealing at $62^{\circ} \mathrm{C}$ for 30 second and extension at $72^{\circ} \mathrm{C}$ for 30 second with a final extension at $72^{\circ} \mathrm{C}$ for 10 minutes (Plate 01 and 02).

\section{Agarose gel electrophoresis}

The amplified product was checked for quality and quantity by agarose gel electrophoresis as described by Sambrook and Russell (2001).

\section{PCR amplification and restriction digestion}

This is a useful technique for screening of sequence variations that give rise to RE sites. Such analysis involves amplification of a specific region of DNA encompassing the polymorphic RE sites and digestion of the amplified DNA fragment with the respective RE. This technique allowed the identification of only two alleles per locus and is slow to be used with large genome size in mammals, where about $3 \times 10^{9}$ individual nucleotides are present in the total DNA content.

Restriction digestion of the PCR product was performed in a total volume of $30 \mu \mathrm{l}$, having $10 \mathrm{X}$ buffer Tango $2 \mu \mathrm{l}$, PCR reaction mixture $10 \mu$, restriction enzyme fast digest (Sph I /Pae1) (10 units/ $\mu$ l) $1 \mu \mathrm{l}$ and nuclease free water $17 \mu \mathrm{l}$. The reaction mixture was spinned for few seconds for uniform mixing and then incubated at $37^{\circ} \mathrm{C}$ for 30 minutes in the water bath (Table 2).

\section{Agarose gel electrophoresis of digested product}

The restriction fragments of different lengths were separated on $2 \%$ agarose gel electrophoresis run at $80 \mathrm{~V}$ for 1 hour. The lengths of all fragments generated by restriction enzyme ((Sph I /Pae1) digestion were compared with O' GeneRuler ${ }^{\text {TM }}$ (Fermentas Life Science) 100bp DNA ladder (range 100-1000bp) as a molecular size marker. The PCR-RFLP DNA bands were visualized under UV light and documented by gel documentation system (BioRad, USA). The band size of each sample was judged by comparing with molecular size marker and recorded (Plate 03, 04).

\section{Statistical analysis}

The analysis was carried out with appropriate Statistical method using software's in the computer centre of the institute under the following headings:

\section{Restricted Maximum Likelihood Method (REML)}

\section{Estimation of breeding value}

The single trait animal model was considered for estimation of breeding value using WOMBAT software (Meyer, 2010). The following animal model was considered:

$$
\mathrm{Y}_{\mathrm{ijk}}=\mathrm{X} \mathrm{b}_{\mathrm{i}}+\mathrm{Z} \mathrm{u}_{\mathrm{j}}+\mathrm{e}_{\mathrm{ijk}}
$$


where, $\begin{array}{ccc}\mathrm{Y}_{\mathrm{ijk}} & = & \mathrm{k}^{\text {th }} \text { observation of } \mathrm{j}^{\text {th }} \text { random effect of } \\ \mathrm{i}^{\text {th }} \text { fixed effect } & \\ \mathrm{b}_{\mathrm{i}} & = & \text { Vector of observation of fixed effect } \\ \mathrm{X} & = & \text { Incidence matrix of fixed effect } \\ \mathrm{u}_{\mathrm{j}} & = & \text { Vector of additive genetic effect } \\ \text { (animal effect) } & & \\ \mathrm{Z} & = & \text { Incidence matrix of random effect } \\ \mathrm{e}_{\mathrm{ijk}} & = & \text { Vector of residual errors }\end{array}$

\section{Association estimation}

Based on the adjusted records, pertaining to milk yield and its constituents on Sahiwal and Karan Fries cattle maintained at ICAR-NDRI, Karnal, regression analysis was carried out to identify SNPs contributing significantly to the variation in milk and its constituents.

$$
\begin{aligned}
& \text { where, }
\end{aligned}
$$

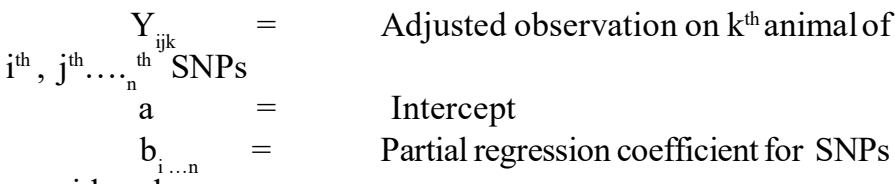

$$
\begin{aligned}
& \text { considered } \\
& \mathrm{Y}_{\mathrm{ij} k \mathrm{k}}=\mathrm{a}+\mathrm{b}_{\mathrm{i}} \mathrm{SNP}_{\mathrm{i}}+\mathrm{b}_{\mathrm{j}} \mathrm{SNP}_{\mathrm{j}}+\ldots \ldots \mathrm{b}_{\mathrm{n}} \mathrm{SNP}_{\mathrm{n}}+\mathrm{e}_{\mathrm{ijk}} \\
& \text { variable } \\
& \mathrm{SNP}_{\mathrm{i}, \mathrm{j} . \mathrm{n}}=\quad \text { Effect of SNPs taken as independent } \\
& \mathrm{e}_{\mathrm{ijk}}=\quad \text { Random error } \operatorname{NID}\left(0, \dot{\mathrm{o}}_{\mathrm{e}}^{2}\right)
\end{aligned}
$$

\section{Effect of genotypes on breeding value}

The relative contribution of Genotypes to breeding value of the animal for milk yield and milk constituents was assessed using the following model:

$$
\mathrm{Y}_{\mathrm{ij}}=\mu+\mathrm{G}_{\mathrm{i}}+\mathrm{e}_{\mathrm{ij}}
$$

Table 1 The standard programme for PCR Reaction mix

\begin{tabular}{llc}
\hline PCR component & Volume $(\mu \mathrm{l})$ & Final concentration \\
\hline 2X PCR Master Mix (Fermentas) & 12.5 & $02 \mathrm{X}$ \\
Deionised water (DNAase free water) & 7.5 & $\ldots .$. \\
Forward primer & 1.0 & $10 \mathrm{pmole}$ \\
Reverse primer & 1.0 & $10 \mathrm{pmole}$ \\
Genomic DNA $(30 \mathrm{ng} / \mu \mathrm{l})$ & 3.0 & $90 \mathrm{ng} / \mathrm{il}$ \\
Total & 25.0 & \\
\hline
\end{tabular}

Table 2 Compositions of restriction enzyme reaction mixture

\begin{tabular}{lc}
\hline Reagent & Quantity $(\mu 1)$ \\
\hline Restriction enzyme $(10$ units $/ \mu 1)$ & 1.0 \\
10 X Buffer Tango & 2.0 \\
PCR reaction mixture & 10.0 \\
Nuclease free water & 17.0 \\
Total & 30.0 \\
\hline
\end{tabular}

where,

$$
\begin{array}{ll}
Y_{i j} & =\quad \text { Breeding value of } j^{\text {th }} \text { animal of } i^{\text {th }} \text { genotype } \\
m & =\text { Overall mean } \\
G_{i} & \left.=\text { Effect of } i^{\text {th }} \text { genotypes (SNPs/ haplotypes }\right) \\
e_{i j} & =\text { Residual error NID }\left(0, \sigma^{2}\right)
\end{array}
$$

\section{Results and discussion}

\section{PCR-Restriction fragment patterns and genotyping at Exon-1of AAT gene (448 bp) in Sahiwal}

PCR-RFLP analysis of PCR products were carried out using reported Sph I Pae lenzyme for 100 Sahiwal cattle. Exon 1 with 448 bp exhibited three genotype $\mathrm{AA}(448), \mathrm{AB}(448+313+135 \mathrm{bp})$, $\mathrm{BB}(313+135 \mathrm{bp})$ having corresponding genotype frequencies $0.20,0.45,0.35$ and gene frequencies of 0.42 (A) and 0.58 (B). These genotypes of $448 \mathrm{bp}$ are highly significant for FL305DMY, FLTMY, FL305DSNFY and non significant for FL305 DFY and FL305DPY. The mean \pm SE of AA genotype for FL305DMY, FLTMY, FL305DFY, FL305DSNFY, FL305DPY were 1711.95 \pm 8.06 $\mathrm{kg}, 1923.30 \pm 11.5 \mathrm{~kg}, 100.5 \pm 0.66 \mathrm{~kg}, 154.03 \pm 0.13 \mathrm{~kg}$ and 43.99 $\pm 0.15 \mathrm{~kg}$ respectively and for $\mathrm{AB}$ genotype were $1869.67 \pm 5.37$ $\mathrm{kg}, 2057.16 \pm 7.65 \mathrm{~kg}, 100.33 \pm 0.44 \mathrm{~kg}, 155.35 \pm 0.08 \mathrm{~kg}, 43.77 \pm$ $0.10 \mathrm{~kg}$ respectively and for BB genotype were $1789.01 \pm 6.09 \mathrm{~kg}$, $2001.15 \pm 8.67 \mathrm{~kg}, 100.25 \pm 0.50 \mathrm{~kg}, 154.79 \pm 0.10 \mathrm{~kg}, 44.02 \pm 0.11$ $\mathrm{kg}$ respectively. $\mathrm{AB}$ genotype was found to be superior for FL305DMY, FLTMY, FL305DSNFY traits and AA genotype was superior for FL305DFY and BB genotype was superior for FL305DPY trait (Table 03 and 04). The result was in agreement with Li et al. (2010) in Chinese Holstein and reported significant for milk fat percentage, milk protein percentage and 305-day milk yield. They concluded that AAT is a potential candidate gene influencing milk production traits and could be implemented in breeding programmes to improve the production performance of Chinese Holstein cattle. 
Fig.1Amplified PCR product of $448 \mathrm{bp}$ of A A $T$ e $n$ e electrophoresed on $2 \%$ agarose in Sahiwal Cattle

M:100bp DNA ladder 1-14 :Amplified PCR product

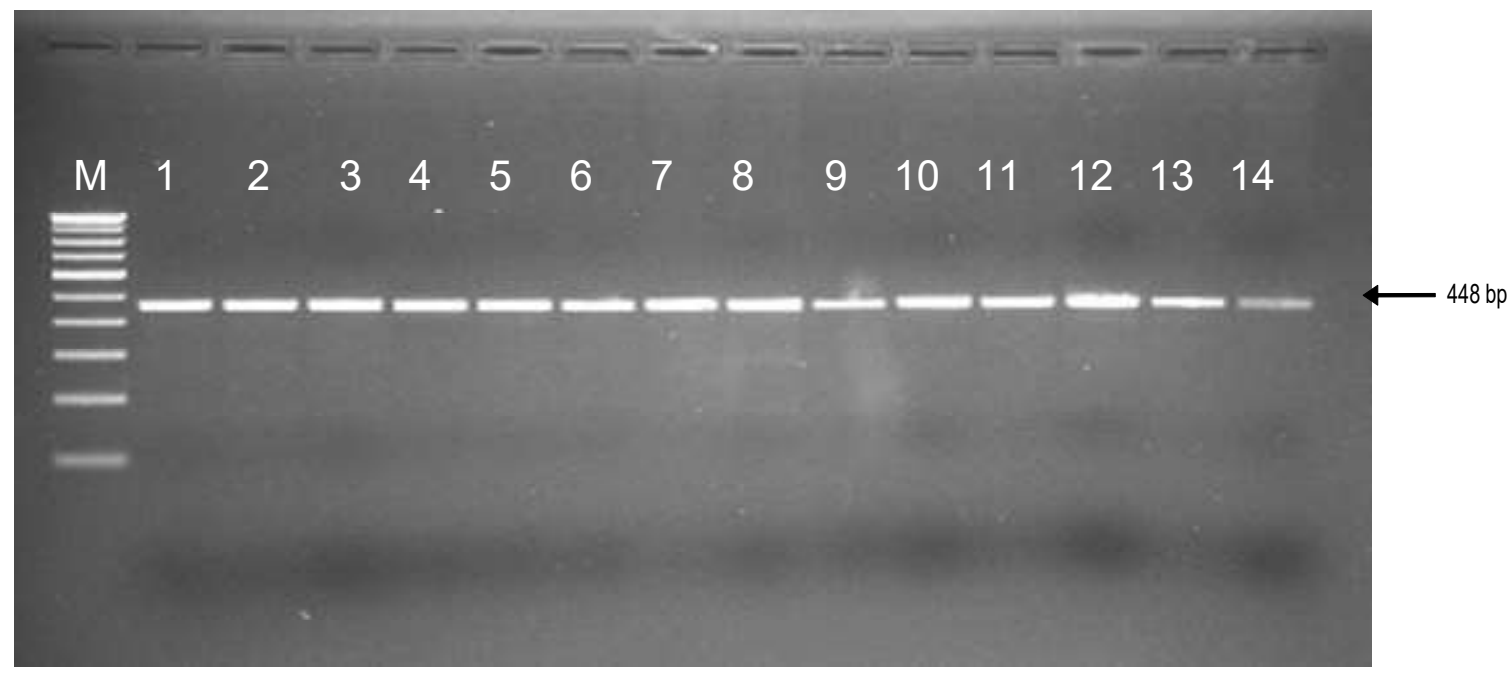

Fig. 2Amplified PCR product of $448 \mathrm{bp}$ of AAT Gene electrophoresed on $2 \%$ agarose in Karan Fries Cattle

M:100bp DNA ladder 1-18:Amplified PCR product

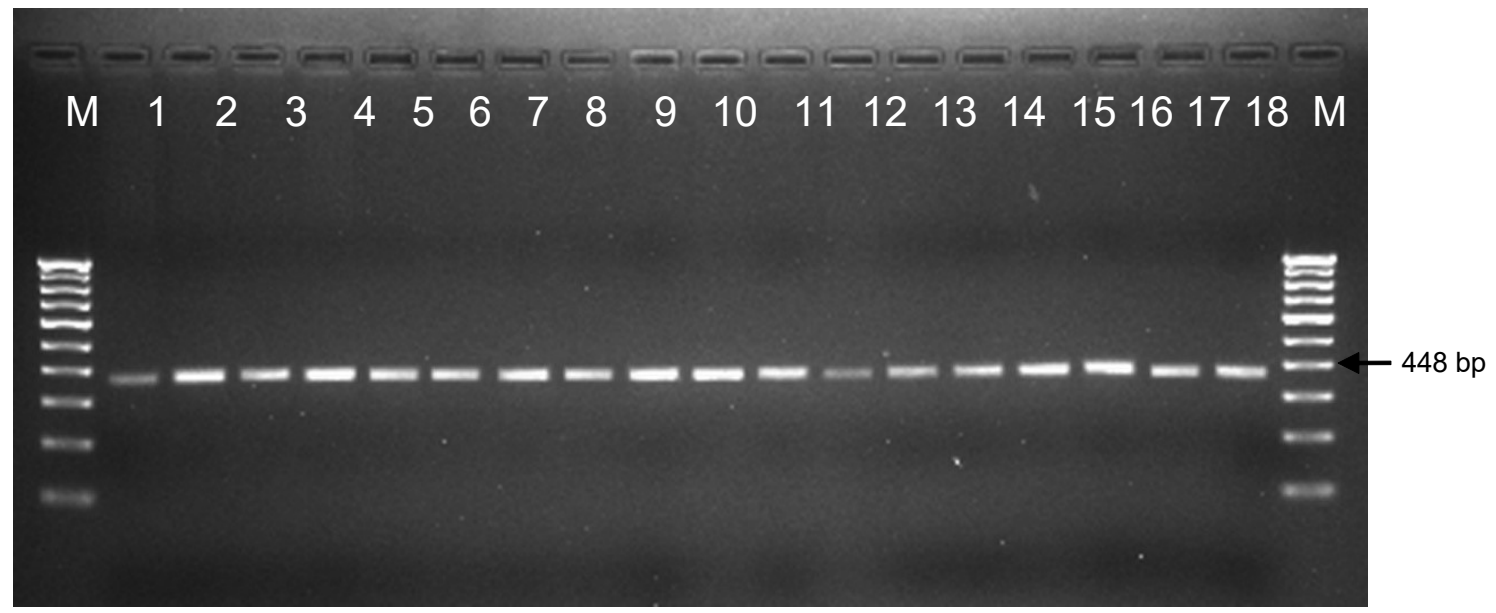

Fig.3 Gel Electrophoresis with 2 $\%$ Agrose gel stained with Ethidium Bromide showing PCR-RFLP pattern of AAT gene digested with $S p h 1$ in Sahiwal

M 100bp DNA ladder Lanes $\mathrm{AB}=(448+313+135)$ $\mathrm{BB}=(313+135)$ $\mathrm{AA}=(448)$

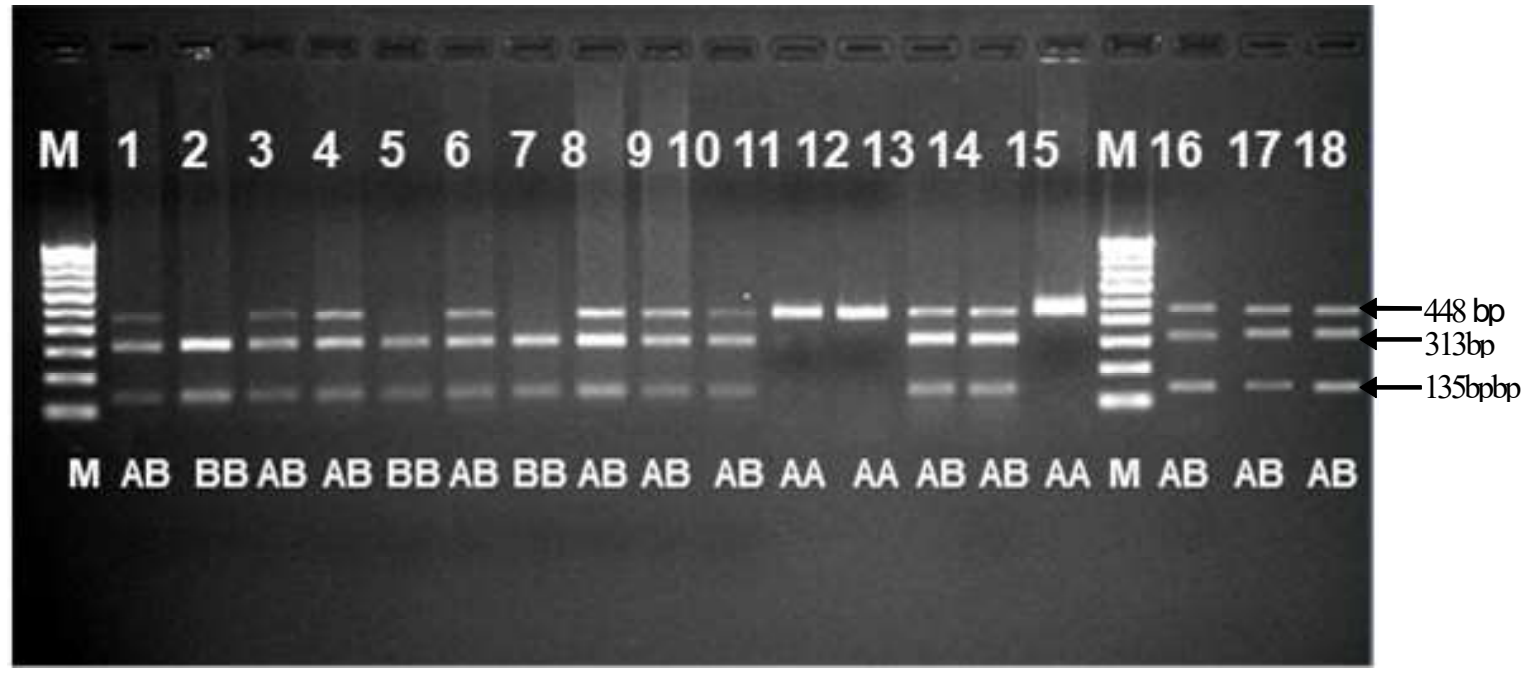

The result is also in agreement with Kheiripour et al. (2014) in Holstein dairy cows and reported that the cows of AB genotype had higher milk fat percentage than those of genotype AA. Cows with $\mathrm{AB}$ genotype showed $0.07 \%$ higher fat $\%$ and $0.02 \%$ higher protein $\%$ as compared to AA genotype. It was concluded that the association value could be implemented as a marker in breeding programmes for these traits.

\section{Regression equation}


Fig. 4 Gel Electrophoresis with 2 $\%$ Agrose gel stained with Ethidium Bromide showing PCR-RFLP pattern of AAT gene digested with $S p h$ I in Karan Fries

M 100bp DNA ladder $\mathrm{L}$ a $\mathrm{n}$ e $\mathrm{s}$ A $\mathrm{B}=$ $(448+313+135)$ $\mathrm{BB}=(313+135)$ $\mathrm{AA}=(448)$

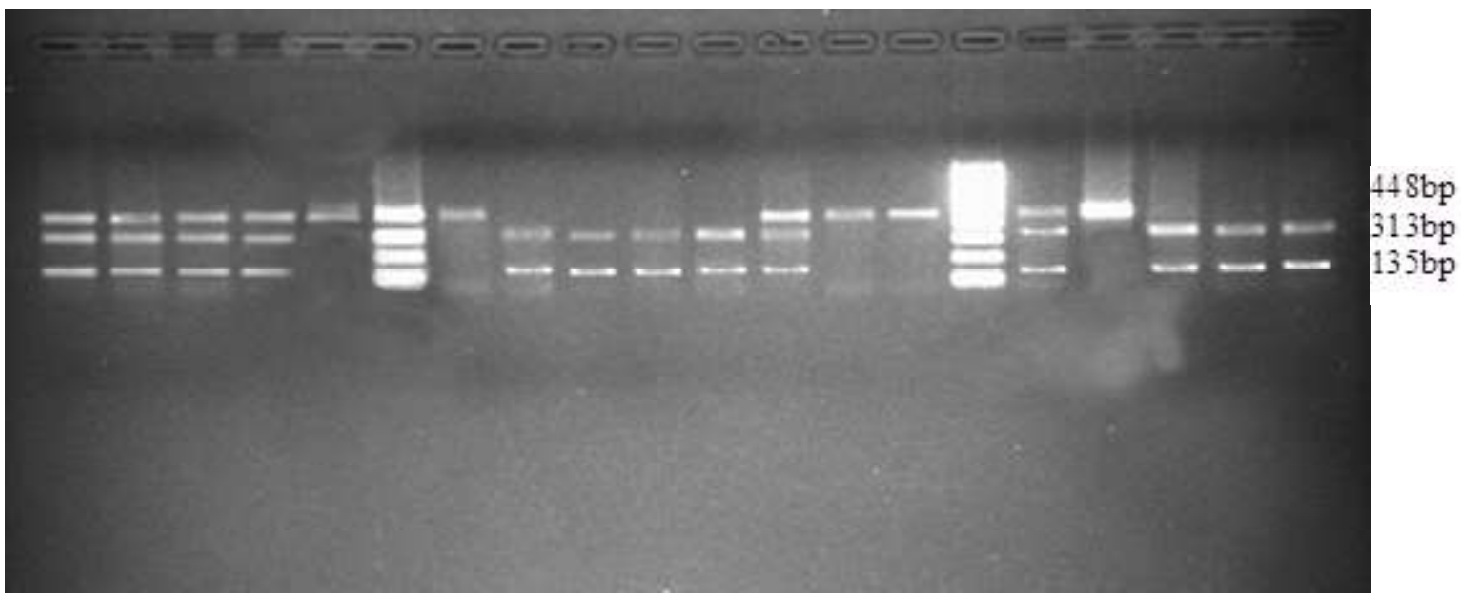

Table 3 ANOVA for Exon 1 of AAT gene in Sahiwal

\begin{tabular}{|c|c|c|c|c|}
\hline Source & $\mathrm{df}$ & SS & MSS & F-value \\
\hline \multicolumn{5}{|l|}{$\overline{\text { FL305DMY }}$} \\
\hline Genotype & 2 & 367923 & 183962 & $141.76^{* *}$ \\
\hline Error & 97 & 125877 & 1298 & \\
\hline Total & 99 & 493801 & & \\
\hline \multicolumn{5}{|l|}{ FLTMY } \\
\hline Genotype & 2 & 253159 & 126580 & $48.11^{* *}$ \\
\hline Error & 97 & 255195 & 2631 & \\
\hline Total & 99 & 508355 & & \\
\hline \multicolumn{5}{|l|}{ FL305DFY } \\
\hline Genotype & 2 & 0.81 & 0.40 & 0.05 \\
\hline Error & 97 & 856.28 & 8.82 & \\
\hline Total & 99 & 857.09 & & \\
\hline \multicolumn{5}{|l|}{ FL305DSNFY } \\
\hline Genotype & 2 & 24.64 & 12.32 & $34.90 * *$ \\
\hline Error & 97 & 34.24 & 0.35 & \\
\hline Total & 99 & 58.89 & & \\
\hline \multicolumn{5}{|l|}{ FL305DPY } \\
\hline Genotype & 2 & 1.42 & 0.71 & 1.52 \\
\hline Error & 97 & 45.52 & 0.46 & \\
\hline Total & 99 & 46.95 & & \\
\hline
\end{tabular}

* Significant $(\mathrm{p}<0.05) \quad * *$ Highly significant $(\mathrm{p}<0.01)$

The significance of association of SNP with different performance traits were estimated by constructing the regression equation and the best fit equation for each of them is given below:

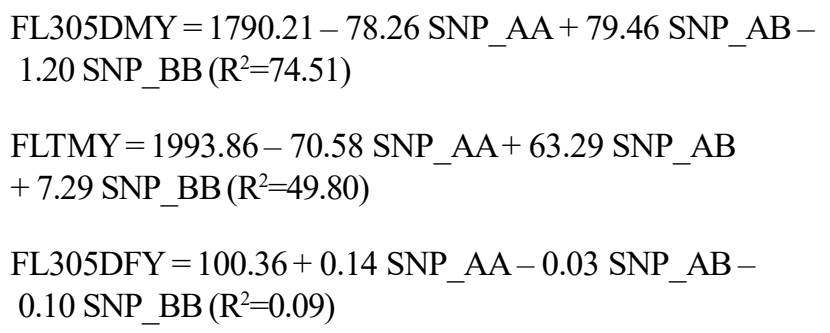

FL305DSNFY $=154.72-0.69 \mathrm{SNP} \_\mathrm{AA}+0.62 \mathrm{SNP} \_\mathrm{AB}$ $+0.06 \mathrm{SNP} B \mathrm{BB}\left(\mathrm{R}^{2}=41.85\right)$

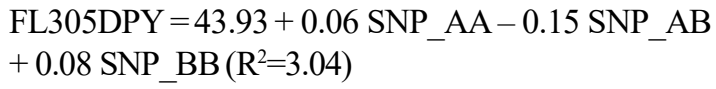

\section{PCR-Restriction fragment patterns and genotyping at exon 10 f AAT gene (448 bp) in Karan Fries Cattle}

PCR-RFLP analysis of PCR products were carried out using reported Sph I /Pae 1 enzyme for 115 Karan Fries animals. The $448 \mathrm{bp}$ has three genotypes AA (448), AB (448+313+135bp), BB $(313+135 \mathrm{bp})$ having genotype frequencies $0.29,0.21,0.50$ 
respectively and gene frequencies are 0.39 (A) and 0.61 (B). These FL305DFY, FL305DSNFY, FL305DPY were 3443.20 $\pm 6.32 \mathrm{~kg}$, genotypes are highly significant for FL305DMY, FLTMY, $4462.96 \pm 6.32 \mathrm{~kg}, 130.70 \pm 6.93 \mathrm{~kg}, 277.36 \pm 0.07 \mathrm{~kg}$ and $112.57 \pm$ FL305DSNFY and FL305DPY and non significant for FL305 DFY. $\quad 0.06 \mathrm{~kg}$ respectively and for AB genotypes were $3621.18 \pm 7.42$ The mean \pm SE of AA genotype for FL305DMY, FLTMY, $\quad \mathrm{kg}, 4640.94 \pm 7.42 \mathrm{~kg}, 139.89 \pm 8.13 \mathrm{~kg}, 279.00 \pm 0.08 \mathrm{~kg}, 114.35 \pm$

Table 4 Least Square Mean and Standard Error for milk production traits

\begin{tabular}{llc}
\hline Genotype & $\mathrm{N}$ & Mean $(\mathrm{Kg}) \pm \mathrm{SE}$ \\
\hline FL305DMY & 20 & $1711.95 \pm 8.06^{\mathrm{a}}$ \\
AA & 45 & $1869.67 \pm 5.37^{\mathrm{b}}$ \\
AB & 35 & $1789.01 \pm 6.09^{\mathrm{c}}$ \\
BB & & \\
FLTMY & 20 & $1923.3 \pm 11.50^{\mathrm{a}}$ \\
AA & 45 & $2057.16 \pm 7.65^{\mathrm{b}}$ \\
AB & 35 & $2001.15 \pm 8.67^{\mathrm{c}}$ \\
BB & & \\
FL305DFY & 20 & $100.51 \pm 6.64$ \\
AA & 45 & $100.33 \pm 4.43$ \\
AB & 35 & $100.25 \pm 5.02$ \\
BB & & \\
FL305DSNFY & 20 & $154.03 \pm 13.30^{\mathrm{a}}$ \\
AA & 45 & $155.35 \pm 8.90^{\mathrm{b}}$ \\
AB & 35 & $154.79 \pm 10.00^{\mathrm{a}}$ \\
BB & & \\
FL305DPY & 20 & $43.99 \pm 15.30^{\mathrm{a}}$ \\
AA & 45 & $43.77 \pm 10.20^{\mathrm{a}}$ \\
AB & 35 & $44.02 \pm 11.60^{\mathrm{b}}$ \\
BB &
\end{tabular}

The mean values with different superscript alphabet indicate highly significant difference $(\mathrm{p}<0.05)$ among themselves

Table 5 ANOVA for Exon 1 of AAT gene in Karan Fries

\begin{tabular}{|c|c|c|c|c|}
\hline Source & df & SS & MSS & F-value \\
\hline \multicolumn{5}{|l|}{$\overline{\text { FL305DMY }}$} \\
\hline Genotype & 2 & 443214 & 221607 & $167.93 * *$ \\
\hline Error & 112 & 147797 & 1320 & \\
\hline Total & 114 & 591011 & & \\
\hline \multicolumn{5}{|l|}{ FLTMY } \\
\hline Genotype & 2 & 443214 & 221607 & $167.93 * *$ \\
\hline Error & 112 & 147797 & 1320 & \\
\hline Total & 114 & 591011 & & \\
\hline \multicolumn{5}{|l|}{ FL305DFY } \\
\hline Genotype & 2 & 1270.83 & 635.41 & 0.40 \\
\hline Error & 112 & 177744.97 & 1587.00 & \\
\hline Total & 114 & 179015.81 & & \\
\hline \multicolumn{5}{|c|}{ FL305DSNFY } \\
\hline Genotype & 2 & 38.35 & 19.17 & $115.47 * *$ \\
\hline Error & 112 & 18.60 & 0.16 & \\
\hline Total & 114 & 56.95 & & \\
\hline \multicolumn{5}{|l|}{ FL305DPY } \\
\hline Genotype & 2 & 44.29 & 22.14 & $140.28 * *$ \\
\hline Error & 112 & 17.68 & 0.15 & \\
\hline Total & 114 & 61.97 & & \\
\hline
\end{tabular}

**Highly significant $(\mathrm{p}<0.01)$ 
Table 6 Least Square Mean and Standard Error for milk production traits

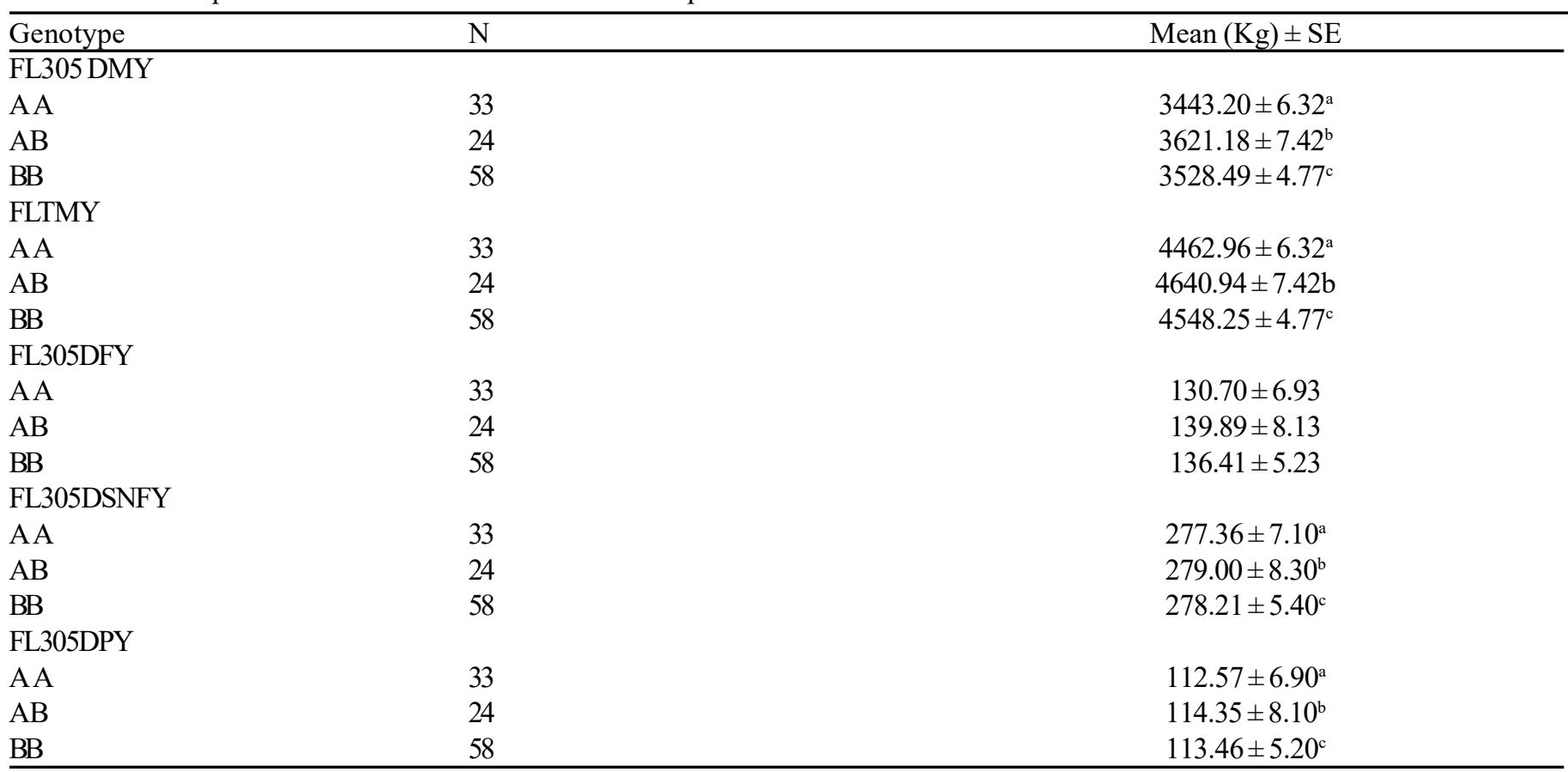

The mean values with different superscript alphabet indicate highly significant difference $(\mathrm{p}<0.05)$ among themselves

$0.08 \mathrm{~kg}$ respectively and for $\mathrm{BB}$ genotypes were $3528.49 \pm 4.77$ $\mathrm{kg}, 4548.25 \pm 4.77 \mathrm{~kg}, 136.41 \pm 5.23 \mathrm{~kg}, 278.21 \pm 0.05 \mathrm{~kg}, 113.46 \pm$ $0.05 \mathrm{~kg}$ respectively. AB genotype was superior for all traits (Table 05 and Table 06).

The result is in agreement with Li et al. (2010) in Chinese Holstein and reported significant for milk fat percentage, milk protein percentage and 305-day milk yield. They concluded that AAT is a potential candidate gene influencing milk production traits and could be implemented in breeding programmes to improve the production performance of Chinese Holstein cattle.

The result is also in agreement with Kheiripour et al. (2014) in Holstein dairy cows and reported that the cows of AB genotype had higher milk fat percentage than those of genotype AA. Cows with $\mathrm{AB}$ genotype showed $0.07 \%$ higher fat $\%$ and $0.02 \%$ higher protein $\%$ as compared to AA genotype. It was concluded that the association value could be implemented as a marker in breeding programmes for these traits.

\section{Regression equation}

The significance of association of SNP with different performance traits were estimated by constructing the regression equation and the best fit equation for each of them is given below:

FLW305DMY $=3530.96-87.76 \mathrm{SNP} \_$AA $+90.22 \mathrm{SNP} \_$AB $-2.47 \mathrm{SNP} B \mathrm{BB}\left(\mathrm{R}^{2}=74.99\right)$
FLTMY $=4550.72-87.76$ SNP_AA + 90.22 SNP_AB 2.47 SNP_BB $\left(\mathrm{R}^{2}=74.99\right)$

FL305DFY $=135.66-4.97 \mathrm{SNP}$ AA $+4.22 \mathrm{SNP}$ AB

$+0.74 \mathrm{SNP} \_\mathrm{BB}\left(\mathrm{R}^{2}=0.71\right)$

FL305DSNFY $=278.19-0.83$ SNP_AA +0.81 SNP_AB $+0.01 \mathrm{SNP} B \mathrm{BB}\left(\mathrm{R}^{2}=67.34\right)$

FL305DPY $=113.46-0.88 \mathrm{SNP} \_\mathrm{AA}+0.88 \mathrm{SNP}$ AB 0.33 SNP_BB $\left(\mathrm{R}^{2}=71.47\right)$

\section{Conclusions}

PCR-RFLP analysis of PCR products was carried out using Sph I /Pae 1 for 100 Sahiwal cattle. These genotypes of exon 1 with $448 \mathrm{bp}$ are highly significant for FL305DMY, FLTMY, FL305DSNFY and non significant for FL305 DFY and FL305DPY. AB genotype was superior for FL305DMY, FLTDMY, FL305DSNFY traits and AA genotype was superior for FL305DFY and BB genotype was superior for FL305DPY trait. PCR-RFLP analysis of PCR products were carried out using, Sph I/Pae 1 for 115 Karan Fries animals. These genotypes of exon 1 with 448 bp are highly significant for FL305DMY, FLTMY, FL305DSNFY and FL305DPY and non significant for FL305 DFY. AB genotype was observed superior for all traits under present investigation. 


\section{References}

BAHS (2014) Basic Animal Husbandry Statistics. Department of Animal Husbandry, Dairying \& Fisheries. Ministry of Agriculture, Govt. of India

Carrell RW, Jeppsson JO, Laurell CB, Brennan SO, Owen MC, Vaughan L, Boswell DR (1982) Structure and variation of human alpha-1antitrypsin. Nature 298: 329-334

Kheiripour MH, Mahdavi AH, Rahmani HR, Soltani-Ghombavani M, Edriss MA (2014) Association of polymorphism in the alpha-1-antitrypsin gene with milk production traits in Holstein dairy cows. South Afr J Anim Sci 44 (2): 155-160

Li QL, Zhang ZF, Wang CF, Yang H, Wang HM, Li JB, Huang JM, Zhong JF (2010) Association of polymorphism of the alpha 1-antitrypsin gene with milk production traits in Chinese Holstein. South Afr J Anim Sci 40: 113-120

Livestock Census, (2012) $19^{\text {th }}$ All India Livestock Census. Department of Animal husbandry, Dairying and Fisheries. Ministry of agriculture. Government of India

Meyer K (2010) WOMBAT-A Tool for Mixed Model Analyses in Quantitative Genetics by Restricted Maximum Likelihood (REML). J Zhejiang Univ Sci 8(11): 815-821

Nivsarkar AE, Vij PK, Tantia MS (2000) Animal Genetic Resources of India: Cattle and Buffalo. ICAR publication, New Delhi

Reinhardt TA, Lippolis JD, Nonnecke BJ, Sacco RE (2012) Bovine milk exosome proteome. J Proteomics 75(5): 1486-92

Sambrook J, Russell DW (2001) Molecular cloning. A laboratory manual $3^{\text {rd }}$ Edn. Cold Pring Harbor Laboratory Press, New York 